\title{
Constitutionalizing Single Party Leadership in Vietnam: Dilemmas of Reform
}

\author{
Thiem Hai BUI* \\ Institute for Legislative Studies - Research Management Board, Vietnam \\ thiembui@gmail.com
}

\begin{abstract}
The supremacy of the Communist Party of Vietnam (CPV) has been the basic norm in Vietnam's constitution since 1980. While it was not changed in the final constitutional amendments in 2013, this grundnorm was seriously debated during the constitutional reform process between $20 \mathrm{IO}^{2} 2 \mathrm{I}_{3}$, thus indicating a shift in the constitutional dialogue in Vietnam. This article traces the history of this basic norm throughout constitutional amendments of the Socialist Republic of Vietnam (SRV) and assesses how the basic norm has become increasingly contested. Contestations over this basic norm have played out markedly over the recent constitutional reform process. The discursive power in these contestations has shaken the rationality-based legitimacy of this basic norm to its root. The continuing dominance of this norm depends to a large extent on how the Vietnamese party-state's practical policy-making and policy implementation initiatives address the increasing tension between the supremacy of the CPV and other principles in the constitution.
\end{abstract}

The Communist Party of Vietnam (CPV) is the centrepiece of the socialist constitutional system of the country. Under the CPV's leadership, many versions of the constitution have been produced and amended. However, the relationship between the CPV and the constitutions adopted by it has been under-researched. The CPV too often resorts to historical arguments to justify its leadership over state and society as the basic norm in Vietnam's constitutional system. Current accounts of this basic norm take its "historical" grounding at face value and fail to provide critical insights into the context of constitutional history. This article seeks to unpack the historical grounding of the basic norm of the CPV leadership in the constitution and to shed clearer light on the implications of this norm in contemporary Vietnamese governance.

The very first seeds of the basic norm were sowed in the 1959 Constitution of the Democratic Republic of Vietnam (I959 Constitution) ${ }^{\mathrm{I}}$ through the democratic centralism principle. In I980, the idea of party leadership and supremacy over the

\footnotetext{
* $\quad$ Researcher at the Institute for Legislative Studies in Ha Noi; PhD (UQ), MA (SOAS).

I. 1959 Constitution of the Democratic Republic of Vietnam (adopted 3I December 1959) [1959 Constitution].
} 
entire constitutional and legal structure was officially constitutionalized. This norm has continued to dominate every subsequent constitutional draft under the CPV administration. While the CPV still maintains an unchallenged monopoly of power in Vietnam, the basic norm of its supremacy has been increasingly subject to serious contestations and challenges from a number of public figures and social actors. This phenomenon became particularly noticeable during the recent process of amending the constitution between $20 \mathrm{II}$ and 20I3. The key argument analyzed in this article is how the discursive power in these contestations has undermined the rationality-based legitimacy ${ }^{2}$ of this basic norm and how crucial institutional reforms are required. In turn, a central question for reforms now is how the destabilizing effects of party leadership over state power can be negated. The continuing dominance of this norm depends to a large extent on how the Vietnamese party-state's practical policy-making and policy implementation initiatives address the increasing tension between this norm of CPV supremacy and other aspects of Vietnam's socialist constitutional system.

This article attempts to investigate the discourse on the party leadership norm in the constitution and highlights important arguments by public figures as well as social actors. It also provides a critical analysis of the ways in which the party leadership norm and the discourse surrounding it affect governance issues in Vietnam. In doing so, this article exposes the different dilemmas that have emerged in the Vietnamese socialist constitutional system. The basic norm of party supremacy presently generates tensions that must be addressed through appropriate mechanisms. There is a need for the CPV to spell out the details of the strategic leadership role of the party over state institutions and the society in order to provide effective solutions to current governance problems.

\section{HISTORICAL GROUNDING OF THE BASIC NORM OF PARTY LEADERSHIP IN THE CONSTITUTION}

In I945, Viet Minh successfully took over political power in Vietnam in the wake of the downfall of Japan's military rule. The Front then established the Democratic Republic of Vietnam (DRV). The Indochinese Communist Party (ICP) was the major political force within Viet Minh and its core members held key positions in both Viet Minh and the Government of the DRV, particularly within the state security apparatus. ${ }^{3}$ While the Constitution Drafting Committee formed in I945 was led by Hồ Chí Minh, a founder of the ICP, and other prominent ICP leaders like Trường Chinh and Nguyễn Lương Bằng, the 1946 Constitution of the Democratic Republic of Vietnam (1946 Constitution $)^{4}$ itself "gives a generally 'Western democratic' impression". 5 As David

2. In this case, rationality-based legitimacy refers to the Weberian rational-legal authority, which is the grundnorm for CPV leadership. It is the foundation for a legal order and the laws that have been enacted in it.

3. David MARR, Vietnam in 1945: The Quest for Power (Berkeley, CA: University of California Press, I995) at I 52-240.

4. $\quad$ I946 Constitution of the Democratic Republic of Vietnam (adopted 9 November I946).

5. Bernard FALL, The Viet-Minh Regime: Government and Administration in the Democratic Republic of Vietnam (New York: Institute of Pacific Relations, I956) at I3-I4. 
Marr argues, "ICP authority within the state apparatus was still quite limited".6 Indeed, the Viet Minh-led government "still operated on a coalition basis"7 and Viet Minh itself was a broad-based alliance of various political and social forces. The ICP also needed to work with other non-Viet Minh political parties from a range of political spectrums to run the fragile government. For these practical reasons, it was impossible for the ICP to assert its supremacy as a constitutional norm in the I946 Constitution.

The context changed substantially in 1959 when a new constitution was drafted and adopted. By this time, the Workers' Party of Vietnam (WPV), restored from the officially dissolved ICP in I945, had been able to monopolize political power in the DRV although it controlled only the northern territory of Vietnam. The DRV was then firmly wedded to the socialist camp led by the Soviet Union. Under the strong influence of the Communist Party of the Soviet Union (CPSU), the WPV had clearly adopted "a hardened socialist line" in the 1959 Constitution. ${ }^{8}$ Following that line, the party's leadership over the state and society as a basic constitutional norm could have been introduced into the 1959 Constitution. This would also echo Article 126 of the 1936 Constitution of the Union of the Soviet Socialist Republics (USSR), which affirms the leading role of the communist party and recognizes it as "the vanguard of the working people in their struggle to strengthen and develop the socialist system and is the leading core of all organizations of the working people, both public and state". ${ }^{9}$ However, in order to realize the strategic and ultimate goal of unifying the country, the WPV chose not to go that far in the I959 Constitution. In fact, for the purposes of broad-based mobilization of political and social forces in the south of Vietnam, the National Front for the Liberation of the South of Vietnam (NLF) was established in I960 under the auspices of the WPV.

While the 1959 Constitution did not directly refer to the basic norm of party leadership, the fundamental principle of a communist party, that is, democratic centralism (tập trung dân chủ), was introduced for the first time in Article 4 of the I959 Constitution. The provision states that " $\mathrm{t}]$ he National Assembly, the People's Councils at all levels and other state agencies shall all practise the principle of democratic centralism". ${ }^{\text {Iо }}$

Democratic centralism is the paramount organizational principle of any communist party. Conceived of by Lenin, it allows democratic and open discussion of policy issues within the party but requires unity in upholding agreed policies in a hierarchical order (a principle of "freedom of discussion, unity of action"). ${ }^{\text {II }}$ That a party principle had become a constitutionally and legally binding rule on all organs of the state apparatus changed the constitutional landscape profoundly. In practice, it triggered the idea of the

\footnotetext{
6. David MARR, Vietnam: State, War, and Revolution (1945-1946) (Berkeley, California: UC Press, 20I3) at I3.

7. Bernard B FALL, “The North Viet-Nam's New Draft Constitution” (I959) 32(2) Pacific Affairs I78 at I 78 .

8. Mark SIDEL, The Constitution of Vietnam: A Contextual Analysis (Oxford and Portland, Oregon: Hart Publishing, 2009) at 27.

9. 1936 Constitution of the Union of Soviet Socialist Republics (adopted 5 December 1936).

Io. $\quad$ I959 Constitution, supra note I, art 4 .

I I. Vladimir I LENIN, "Report on the Unity Congress of the RSDLP: A Letter to the St Petersburg Workers" (I906), online: Marxists.org <https://www.marxists.org/archive/lenin/works/I906/rucong/viii.htm>.
} 
prominence of party leadership in the constitution as the most important constitutive and regulative norm. As John Gillespie argues, “democratic centralism validated party leadership over state and society". ${ }^{22}$ In the same year as the 1959 Constitution came into force, the WPV organized its Third National Congress and promulgated the new Party Statute, Article ro of which clearly explains the principle of democratic centralism. There are six points in Article ro, but the most important one is the last:

Party resolutions shall be obeyed unconditionally. Individual Party members must obey the Party organizations. The minority must obey the majority. Lower organizations must obey higher organizations. Party organizations throughout the country must obey the National Congress of Delegates and the Central Executive Committee. ${ }^{\mathrm{I} 3}$

As the principle of democratic centralism applied to the entire state apparatus under the 1959 Constitution, the governing institution of the DRV has been frequently referred to as the "party-state". With the victory of the DRV over the Republic of Vietnam in the south in 1975 , the party-state extended its reach to the entire country. In I976, the WPV changed its name to the Communist Party of Vietnam and the DRV became the Socialist Republic of Vietnam (SRV). The SRV and the Soviet Union then signed the Treaty of Friendship and Cooperation (Treaty) in November I978. ${ }^{\mathrm{I} 4}$ This drove the CPV leaders to adopt a new constitution for a unified Vietnam that echoed the 1977 Soviet Constitution. Article 4 of the Treaty states:

The High Contracting Parties will pursue an all-out and consistent struggle for the further strengthening of fraternal relations, of unity and solidarity among socialist countries based on Marxism-Leninism and socialist internationalism. They will bend every effort towards the consolidation of the world socialist system, and will make a vigorous contribution to the development and protection of socialist gains. ${ }^{\mathrm{I}}$

In 1980 , the new constitution of the unified Vietnam provided that the leadership of the CPV over the state and society was a basic norm. Article 4 states:

The Communist Party of Vietnam, the vanguard and the combating staff of the working class, is armed with Marxism-Leninism and is the only force leading the State, the society, and the factor decisive to all victories of the Vietnamese revolution. The Party exists and strives for the interests of the working class and the people of Vietnam. Party organizations shall operate within the framework of the Constitution. ${ }^{16}$

This article is a duplicate of Article 6 of the 1977 Soviet Constitution. By making the party leadership a crucial constitutional norm that undergirds the entire political

\footnotetext{
I2. John GILLESPIE, Transplanting Commercial Law Reform: Developing a 'Rule of Law' in Vietnam (Aldershot, UK: Ashgate Publishing, 2006) at 78.

I3. The Statute of the Workers' Party of Vietnam (adopted on Io September I960), art Io.

I4. The Treaty had the signatures of L.I. Brezhnev, General Secretary of the Central Committee of the CPSU, and A.N. Kosygin, Chairman of the Council of the Ministers, on the USSR side and Le Duan, General Secretary of the Central Committee of the CPV, and Prime Minister Pham Van Dong on the SRV side.

I 5. 1978 Treaty of Friendship and Cooperation between the Socialist Republic of Vietnam and the Soviet Union (signed 3 November 1978).

I6. I980 Constitution of the Socialist Republic of Vietnam (adopted I9 December I980).
} 
regime, the CPV enshrined its political power within the Constitution without leaving any room for challenge on legal-rational grounds. In I992, despite the demise of the Soviet Union, the CPV was still determined to maintain this assertion in Article 4, which was left untouched in the $200 \mathrm{I}$ revision of the 1992 Constitution of the Democratic Republic of Vietnam (I992 Constitution):

The Communist Party of Vietnam, the vanguard of the Vietnamese working class, the faithful representative of the rights and interests of the working class, the toiling people, and the whole nation, acting upon the Marxist-Leninist doctrine and Ho Chi Minh's thought, is the force leading the State and society. Party organizations shall operate within the framework of the Constitution and the law. ${ }^{17}$

The only noticeable change in Article 4 of the 1992 Constitution compared to the corresponding article in the 1980 Constitution of the Socialist Republic of Vietnam (I980 Constitution) is the removal of the word "sole" from the phrase "the force leading the state and society", and the inclusion of "Ho Chi Minh's thought" as one of the forces leading the state and the society. The 2013 Constitution of the Socialist Republic of Vietnam (2013 Constitution) also has some minor alterations to the wording of Article 4 while remaining loyal to the basic norm. Article 4 of the 2013 Constitution now reads:

I. The Communist Party of Vietnam, the vanguard of the Vietnamese working class, simultaneously the vanguard of the toiling people and of the Vietnamese nation, the faithful representative of the interests of the working class, the toiling people, and the whole nation, acting upon the Marxist-Leninist doctrine and Ho Chi Minh's thought, is the leading force of the state and society.

2. The Communist Party of Vietnam maintains intimate contact with the people, serves the people, submits to the people's supervision, and is accountable to the people in its decisions.

3. Party organizations and members of the Communist Party of Vietnam shall operate within the framework of the Constitution and the law. ${ }^{\mathrm{I} 8}$

These changes include the addition of the people's nominal supervisory power over the CPV and subjecting the CPV members, not only organizations, to the Constitution and the law. In the decades following the reunification of Vietnam, the party leadership norm in Article 4 is firmly entrenched in the political system both as a constitutive and regulative basic norm.

\section{CONTESTATIONS OVER THE BASIC NORM OF PARTY LEADERSHIP IN THE RECENT CONSTITUTIONAL REFORM}

The issue of party domination was central to the process of constitutional amendment in Vietnam. It frames almost every other important theme throughout the Vietnamese

\footnotetext{
I7. 1992 Constitution of the Democratic Republic of Vietnam (adopted 25 April I992).

I8. 2013 Constitution of the Socialist Republic of Vietnam (adopted 28 November 20I3).
} 
constitution and the politics of constitutional reform. This issue was challenged throughout dialogues on the threshold of constitutional amendments. Noticeably, it was the dialogues initiated by former high-ranking officials of the Party and the state that have had an enormous impact on the long-standing beliefs on party leadership. In each of the constitutional amendment exercises, the discussions among the elites have contributed to the dynamics of the dialogues, shedding clearer light on the contested knowledge of the basic norm.

In as early as I990, Nguyễn Kiến Giang ${ }^{19}$ seriously questioned the party leadership norm in the constitution. He was well respected by both Party officials and dissidents. He had published a series of influential essays on the theoretical and ideological deadlocks in Vietnam, which were an anathema to the Party. In "Discussion on the Party's Leadership", Giang argued that Article 4 of the I980 Constitution is the root cause of Vietnam's governance problems. ${ }^{20}$ The essay was widely circulated and read by Vietnamese intellectuals. Another prominent intellectual in the early I990s who was very vocal on the role of the Party and the constitution was Phan Đình Diệu. ${ }^{21}$ As a well-respected and responsible citizen, he had made many harsh comments and warnings about issues concerning the country at that time. In a meeting of the Central Committee of the Vietnam Fatherland Front on the draft constitutional amendments on I 2 March I992, he vigorously challenged the validity of Article $4 \cdot{ }^{22}$ The issue of party dominance was raised again from different perspectives in the $200 \mathrm{I}$ discussion on constitutional revision. $^{23}$ Although party-state leaders have always vehemently opposed the removal of Article 4, ongoing discussions of the Party's role and a possible revision of Article 4 are never far away from any debates concerning the Party.

The debates on the role of the CPV in relation to the rule of law, to a law-based state, and to all state institutions and mass organizations stipulated in the constitution including the National Assembly, the State President, the Government, the Court, the Procuracy, the military, Vietnam Fatherland Front, and the Vietnam General Confederation of Labour, are important in understanding the politics of constitutional reform. All actors and institutions involved in constitutional politics are, to some degree, subject to the discursive power of this discourse: it serves as a foundational basis that structures and coordinates their positions, views, and actions. This is true for all involved, from party-state institutions and mass organizations or societal groups, to independent bloggers and dissidents, both local and overseas. However, different actors - each with their own identities and interests - have different assumptions and give different meanings to the debates on party dominance. For example, it was

19. Nguyễn Kiến Giang was a prominent intellectual and once a senior official of the CPV involved in the anti-party affairs in the mid-I960s. He was imprisoned for many years.

20. NGUYEN Kiến Giang, "Suy tư 90-Bàn về sự lãnh đạo của Đảng [Reflection in 90-Discussion on the Party’s Leadership]” Tạp chí Khoa học và Tồ quốc [Science and the Nation Journal] (April I990), online: Talawas <http://www.talawas.org/talaDB/showFile.php?res $=6907 \& \mathrm{rb}=0305>$.

2I. Phan Đình Diệu is a mathematics professor, and was also a member of the Vietnam Fatherland Front Central Committee Presidium in the early i99os.

22. PHAN Đình Diệu, "Phát biểu góp ý kiến về Dự thảo Hiến pháp [Speech on the Draft Constitution]" Diễn đàn của chúng ta [Our Forum] (I 2 March I992), online: Diê̂n đàn của chúng ta <https://diendancuachungta.com/ cac-de-nghi-gop-y-tu-chinh-hp/gop-y-kien-ve-du-thao-hien-phap-phan-dinh-dieu/>.

23. Sidel, supra note 8 at $\mathbf{2} 28$. 
through this process that a number of high-profile party members openly supported legal and constitutional limits to party power. Their arguments demonstrated their interest and belief in a rule-based and rational party leadership. This reflected a fundamental shift in thinking by a number of party members, even those at the apex of the Party, about the legitimacy of party rule. This is the major reason that discussions on this issue were allowed in the lead-up to the adoption of the $20{ }_{3} 3$ Constitution - a situation which stood in stark contrast to previous constitutional debates.

Leaders of the party-state have long asserted that CPV domination is responsible for all of the glorious victories over Vietnam's enemies ${ }^{24}$ (most notably, the colonial and imperialist powers), for securing the country's independence and re-uniting the country, for the success of Đổi Mới and international integration, for bringing about economic prosperity and social justice, and for demonstrating moral righteousness and intellectual superiority. On these grounds, the CPV seems to have established an inspiring legitimacy to rule. One-party rule is cast as the meaning of leadership, with the CPV as "the force leading the state and society". The slogan that "the leadership of the party is the decisive determinant of all victories of the Vietnamese Revolution" became obligatory in every discourse on party leadership. All this illustrates the fundamentally rhetorical underpinnings of CPV legitimacy.

The principle of party leadership or supremacy is codified into rules and norms, both explicitly and implicitly, in the constitution. The most explicit rule is Article 4 of the I 992 Constitution, which implicitly overshadows almost every other article. This rule has become an "absolute truth" that is tightly protected, so that any attack on it would fail to exert any effect or would not be justified at all. Thus, besides the regulative meaning (that is, what discourse or behaviour is permitted and what is prohibited), the rule acts as a constitutive norm in the sense that it shapes who the actor actually is. ${ }^{25}$ Following this line of logic, the CPV claims to have commanded the absolute allegiance of the military in the constitution. However, this claim of paramount supremacy is vague and does not have a fixed meaning: during the process of constitutional amendment, it was challenged and defied, and, therefore, it has undergone subtle shifts over time.

The draft amendment to Article 4 of the 1992 Constitution that was released for public consultation contained significant changes, even though the effects of those changes might still be questioned. The crucial change is that the leaders have accepted to some extent - that the party's leadership is no longer automatically assumed but rather contingent on its fulfilment of responsibilities before the people. The new version added two important stipulations: (I) the accountability of the party to the people in its decision-making; and (2) the subjugation of party members to the Constitution and law. These changes reflect a rough consensus after long deliberations within the party-state about the role of the party and its responsibilities. The 1992 Constitution is silent on a clear role for the party and the relationship between the party as an entity

\footnotetext{
24. Tuong $\mathrm{Vu}$ attributes the persistence of the single-party rule to a number of factors, the most decisive of which being revolutionary violence. See Tuong VU, "The Persistence of Single-Party Dictatorships: The Case of Vietnam” (Working Papers Series, City University of Hong Kong, January 20I2), I 8-I9.

25. John SEARLE, The Construction of Social Reality (Harmondsworth: Penguin Books, I995) 27-28.
} 
towards the law and all other state institutions. Sidel makes a pertinent point on this vagueness:

At each juncture, whether voiced formally or not, a key problem has been that the party is predominant in all of these institutions but that the Constitution does not spell out the party's full or detailed role, making structural change through constitutional revision an even more complicated matter than it otherwise naturally is. ${ }^{26}$

Unlike the institutions of the state like the National Assembly, the State President, the Government, the Supreme People's Court or the Supreme People's Procuracy, there has been no constitutional provision or chapter on the specific role and mandate of the CPV. This intentional gap in the constitution raises questions about the constitutional and legal framework for the CPV. There have been mounting pressures on holding the Party and its members accountable before the people and the law, respectively. In the months leading up to the Eleventh National Congress of the CPV, former National Assembly Chairman Nguyễn Văn An, in an unusual interview with Vietnamnet, expressed his deep dissatisfaction with the constitutional constraints on the Party's power and called for a law on the party to fix "systemic problems". ${ }^{27}$

Vũ Mão, a former senior CPV official, maintained that the idea of subjecting the Party to public supervision and accountability for its decisions would be codified into law. Vũ Mão used to hold high-ranking positions at both the National Assembly and the Vietnam Fatherland Front. At the National Assembly, he served two terms as the Chairman of the Office of the National Assembly and one term as Chairman of the Foreign Affairs Committee. He is one of the very few retired high-ranking officials who frequently speak to the media on controversial issues. With regard to the issue of party leadership more specifically, he requested an addition to the second clause of Article 4:

Party organizations and members must operate within the framework of the Constitution and the law, maintain close contact with the people, serve the people, be subjected to the people's supervision and be held accountable before the people for their decisions, as stipulated by the law. ${ }^{28}$

Another prominent retired official who captured public attention with his statement on the party leadership was Hoàng Thái, a former standing member of the Vietnam Fatherland Front Central Committee. He was instrumental in building the organization of the Vietnam Fatherland Front for decades before his retirement. At a meeting organized by the Vietnam Fatherland Front in February 2013, he made a very sharp comment: "There are laws on the State, the National Assembly, and the Vietnam

26. Sidel, supra note 8 at 6.

27. NGUYẼ̂̃̂N Văn An, "Cựu Chủ tịch Quốc hội bàn việc sửa đổi Hiến pháp [Former Chairman of the National Assembly discusses the Constitutional amendments]" Tuần Việt Nam [Vietnam Weekly] (I6 June 20Io), online: Tuần Việt Nam <http://www.tuanvietnam.net/20Io-o6-24-cuu-chu-tich-quochoi-ban-viec-sua-hien-phap>.

28. VŨ Mão, "Cần trở lại tinh thần Hiến pháp I946 [The need to return to the spirit of the I946 Constitution]" Vietnamnet (6 February 2013), online: Vietnamnet <http://vietnamnet.vn/vn/chinh-tri/ I08600/can-tro-lai-tinh-than-hien-phap-I946.html>. 
Fatherland Front, but no law on the party. There must be a law on the party to ensure openness and transparency as well as to avoid arbitrariness." ${ }^{29}$ At the same meeting, Nguyễn Khánh, a former Deputy Prime Minister, requested for the enactment of provisions to provide for the people's exercise of supervisory powers over the Party in accordance with a law on social oversight and feedback. These comments reflected the official view of the Vietnam Fatherland Front, which was embedded in a June 2012 proposal concerning amendments to Article 4. The proposal on the accountability of the Party and its members were put forward with the goal of preventing party members from operating outside the law and engaging in rampant corruption without fear of due punishment. ${ }^{30}$

This bold proposal surprised many observers, since it deviated from the traditional view of the Vietnam Fatherland Front as an organization that is obedient to the Party. The proposed amendment to Article 4, in fact, incorporated substantive concessions by the party-state leaders to produce consensus among the official circle and the people. This indicates the recognition of a new "language game" that has been enlarged for wider participation and contestation.

At the National Assembly meeting on I9 November 2012 to deliberate the constitutional amendments, Trương Trọng Nghĩa, Vice Chairman of the Vietnam Bar Federation and a National Assembly member, explained the nuances of the amended provisions concerning party accountability:

Concerning Article 4 and the Party, we have three different entities: the first is the Communist Party of Vietnam, the second is party organizations, and the third is party members. Designing Article 4, we ignored the most important entity, that is, the Party as a whole. Thus, we stipulate that only Party organizations and members must operate within the framework of the Constitution and law. Concerning Article 4, I add just one more word at the forefront, namely "the Party, Party organizations, and members must operate within the framework of the Constitution and law". ${ }^{3}$

As a lawyer, Trương Trọng Nghĩa understood very well the implications of a legal entity and implicitly pointed to the role of the CPV in relation to the rule of law. He represented the fundamental interest of lawyers as a professional association despite the Vietnam Bar Federation's structural ties to the party-state.

Meanwhile, Petition 72, which represented the efforts of "the newly empowered agents of modernity," questioned the pre-determination of the leadership of a particular political organization and requested that the people elect the leadership. Unlike radical political dissidents inside Vietnam and abroad, this group did not reject the leadership of the party but tried to tie it to the conditions of a free and fair

29. “Góp ý sửa Hiến pháp: Phải có luật về sự lãnh đạo của Đảng [Contribution to the Constitutional Amendments: There Must be a Law on the Party's Leadership]" VnEconomy (19 February 2013), online: VnEconomy <http://vneconomy.vn/20I302I9I00I 53 I 56 PoC9920/gop-y-sua-hien-phap-phai-co-luatve-su-lanh-dao-cua-dang.htm $>$.

30. BUI Hai Thiem, "Liberal Constitutionalism and the Socialist State in an Era of Globalisation: An Inquiry into Vietnam's Constitutional Discourse and Power Structures” (2013) 2 The Global Studies Journal 49.

3I. Văn phòng Quốc hội [Office of the National Assembly (ONA)], Biên bản tổng hợp thảo luận tại hội trường ngày I 6 tháng I I năm 2012 [Minutes of Deliberation at the Plenary Session of the Fourth Meeting of the Thirteenth NA on the Morning of November I6, 20I2]. (Hà Nội: IT Centre of the ONA, 2OI2). 
election in the context of political competition. In an open challenge to the party-state's securitization of Article 4, Hoàng Xuân Phú, a mathematics professor and a signatory to Petition 72, entered the "language game" with a highly critical analysis of the linguistic logic and tactical language used in various provisions of the I992 Constitution:

The above-cited articles demonstrate that wherever necessary, the Constitution drafters remembered to use the word "must" or equivalent to stress the "requirement." They intentionally "forget" to use the word "must" in Article 4. Therefore, the Constitution grants the CPV absolute power without requiring it to implement anything, including the obligation "to strictly abide by the Constitution and law" as stipulated in Article I 2 for the society and societal members. ${ }^{32}$

The collective views of the Group of 72 and Hoàng Xuân Phú were shared by other prominent members of the group, such as Tương Lai, Nguyễn Trung, Tống Văn Công, and Lê Hiếu Đằng - all formerly in the elite ranks of the party-state. They have also been prolific writers on the need for a "peaceful evolution" of the party-state into a democratic institution, advocating a new order in which the willing agency of representatives of the old order plays a crucial role through a political reform embraced in the process of amending the 1992 Constitution. ${ }^{33}$ Nguyễn Trung strongly challenged the principle of party supremacy based on the rule of law, and he insisted, instead, on the supremacy of the constitution. ${ }^{34}$ Tống Văn Công also stressed the inherent tension between the rule of law, or a law-based state, with party supremacy and the inextricable link between the separation of powers and democracy. ${ }^{35}$ Lê Hiếu Đằng argued for the urgent need for political competition. Their discursive power ${ }^{36}$ was strong enough to shape the counter-hegemonic narrative of party domination both in the blogosphere and in the public.

Other groups such as the Vietnam Episcopal Council, a significant religious interest group, and the group Các Công dân Tự do ("Free Citizens"), which represented a large blogosphere interest group, raised similar contestations with different layers of

32. HOANG Xuân Phú, "Uẩn khúc trong Điều 4 Hiến pháp [Ambiguity in Article 4 of the Constitution]" (29 August 20I3), online: Blog Hoàng Xuân Phú, <http://hpsc.iwr.uni-heidelberg.de/hxphu/index.php? page $=$ readwriting \&w $=$ UanKhuatTrongDieu 4 HienPhap-20I $30829>$.

33. See TƯơNG Lai, "Vietnam's Angry Feet," New York Times (6 June 20I3), online: New York Times <http://www.nytimes.com/2013/o6/o7/opinion/vietnams-angry-feet.html?_r=o>; TƯơNG Lai, "Nghĩ về hiện tượng Trần Độ [Reflections on the Tran Do Phenomenon]" (8 August 20I3), online: Viet-studies <http://viet-studies.info/kinhte/TuongLai_HienTuongTranDo.htm>; NGUYEN Trung, "Suy ngẫm về thời cuộc [Reflections on the Era]" (I9 September 20I3), online: Viet-studies <http://viet-studies.info/ NguyenTrung/NguyenTrung_SuyNgamThoiCuoc.htm\#VIII>; LE Hiếu Đằng, "Suy nghĩ trong những ngày nằm bịnh [Reflections during the Days of Illness]" Boxitvn (I 2 August 20I3), online: Boxitvn <http://boxitvn.blogspot.com.au/2013/o8/suy-nghi-trong-nhung-ngay-nam-binh.html>.

34. NGUYỄ̂N Trung, "Hiến pháp và những bất cập của Dự thảo sửa đổi [The Constitution and Problems with the Draft Amendments]" Boxitvn (23 January 20I3), online: Boxitvn <http://www.viet-studies.info/ NguyenTrung/NguyenTrung_DuThaoHienPhap.htm>.

35. TONG Văn Công, "Thư gửi Hội nghị Trung ương 8: Đất nước đòi hỏi cải cách chính trị [Letter to the Eighth Plenum of the CPV Central Committee: The Country Requires Political Reform]" (Hà Nội: 30 September 2013).

36. Discursive power in this meaning refers to the capacity to affect and shape the practice and power relationships by language in a Foucauldian sense. 
meanings concerning party domination and the concentration of power. In March 20I3, the Vietnam Episcopal Council wrote:

The root cause is a lack of distinction between the ruling party and the law-based state. This is reflected in the 1992 Constitution and the draft constitutional amendments continue that line [of vagueness]. On the one hand, Article 74 confirms that the National Assembly is "the highest state power body," and on the other hand, Article 4 asserts that the ruling party is "the force leading the state and society." Is the National Assembly a tool of the ruling party? If so, what is the meaning of the people electing National Assembly members? A truly free choice or a sort of democracy in formality? ${ }^{37}$

The group Cùng viết Hiến pháp had an ambivalent view about party dominance. While they acknowledged the irrelevance of Article 4, they were concerned about the consequences of removing it:

We think that the inclusion of Article 4 in the 1980 Constitution on the Party's leadership is not really necessary, however, it is a historical reality. We believe that in the current circumstance[s], the removal of Article 4 might result in unpredictable consequences for the country's development and stability. ${ }^{38}$

International organizations and NGOs were also deeply interested in the process of constitutional amendments. These international actors took a human rights-based and pluralist approach to the constitutional amendments, using international human rights law as an analytical framework. The Human Rights Watch, for example, stressed that the draft Article 4 "makes pluralism and genuine periodic elections impossible". 39

Meanwhile, Vietnamese non-governmental organisations (NGOs) and representatives of minority groups such as the LGBT, people with disabilities, and those with HIV/AIDS, participated in the discourse, but their perspectives came from a different angle. They did not explicitly contest the principle of party supremacy; instead, they offered a human rights-based approach to the constitution and appealed to international human rights law as their basis of legitimacy in the constitutional dialogue with the party-state. In effect, their identity-based claim for the supremacy of human rights - especially the rights of vulnerable and disadvantaged groups challenged some critical aspects of the party domination principle. They adopted measures that were more accommodating and less confrontational to the party-state. The NGOs mainly took advantage of the space to advocate their views for reform. For example, they organized meetings and conferences, collected comments from the

37. Hội đồng Giám mục Việt Nam [The Vietnam Episcopal Council], "Thư gửi Ủy ban Dự thảo sửa đổi Hiến pháp 1992 nhận định và góp ý sửa đổi Hiến pháp [Letter to the 1992 Constitution Amending Committee on Contributions to the Constitutional Amendments]" ( I March 2013), online: Hội đồng Giám mục Việt Nam <http://www.hdgmvietnam.org/thu-cua-hoi-dong-giam-muc-viet-nam-nhan-dinh-va-gop-y-suadoi-hien-phap/4750.I I6.3.aspx>.

38. "Một số ý kiến về việc sửa đổi Hiến pháp [Some Ideas on the Constitutional Amendments]" Cùng Viết Hiến Pháp [Writing the Constitution Together] (I April 2013), online: Cùng Viết Hiến Pháp <https:// hienphap.files.wordpress.com/2013/04/ykien.pdf $>$.

39. Human Rights Watch, "Letter to Chairman Nguyen Sinh Hung: Amended Constitution” (23 October 2013), online: Human Rights Watch <https://www.hrw.org/news/2013/10/22/letter-chairman-nguyensinh-hung-re-amended-vietnam-constitution $>$. 
public, and used the official channels to convey their ideas for reforms. In March 20I3, representatives from thirty-five Vietnamese NGOs met with the Constitution Amending Committee representatives to submit their petition. These phenomena have never been seen in previous constitutional amendment exercises.

\section{IMPLICATIONS OF THE DISCOURSE ON PARTY LEADERSHIP AND RISING TENSIONS IN THE CONSTITUTIONAL AND LEGAL FRAMEWORK}

Throughout the process of constitutional amendment, it was clear that various societal organizations and individuals were focused on influencing the amendment to Article 4 of the Draft Constitution. These actors were trying to illustrate alternatives to the wellestablished narratives on party-state dominance over the entire political system and the kind of power that the party holds. Their message was that the party-state had mistaken power for influence. Influence, which is relative and situation-specific, is a psychological relationship based on ties that transcend momentary interests. ${ }^{4 \circ}$ It was argued, however, that party-state leaders have employed strategies and tactics to transform the raw attributes of power into political influence through generating rationalities and consensus. There is a strong argument that the Party's influence and power is indeed momentary compared to the permanent national interests, although it has more than three million members and has been in power for decades without any challenge. ${ }^{4 \mathrm{I}}$ The party theorists only provided an indirect response to this argument that was based mainly on historical grounding, but was nevertheless lacking in coherence and comprehensiveness. ${ }^{42}$ As there were obvious flaws in the rational counter-argument, the Party chose to respond with practical, politically-expedient statements.

The response from the party-state leadership was a mixture of concession, coercion, and co-optation. In the first major reaction, CPV Secretary General Nguyễn Phú Trọng labelled those demanding the removal of Article 4, non-politicization of the military, and separation of powers as politically and ideologically backward. ${ }^{43}$ However, the

40. Richard Ned LEBOW, “Classical Realism,” in Tim DUNNE, Milja KURKI \& Steve SMITH, eds, International Relations Theories: Discipline and Diversity, $2 \mathrm{~d}$ ed (Oxford: Oxford University Press, 2007) 52 at 58.

4I. VO Thi Hao, "Sửa Hiến pháp: Cưỡng chế hay tái sinh [Amending the Constitution: Coerce or Reincarnate]" BBC Vietnamese (26 July 20II), online: BBC Vietnamese <http://www.bbc.com/ vietnamese/vietnam/20I I/O7/I I 0726_vothihao_constitution.shtml>.

42. NGUYEN Thanh Tu, "Khẳng định vai trò lãnh đạo của Đảng trong Hiến pháp là hợp lý, hợp tình [Asserting the leadership role of the Party in the Constitution is both rational and emotional]" Quân độ $i$ nhân dân [People's Army Newspaper] (I7 February 20I3), online: Quân đội nhân dân <http://www. qdnd.vn/qdndsite/vi-vn/6r/43/chong-dien-bien-hoa-binh/khang-dinh-vai-tro-lanh-dao-cua-dang-tronghien-phap-la-hop-ly-hop-tinh/2292 I9.html>; TRUONG Giang Long, "Sự lãnh đạo đúng đắn, sáng tạo của Đảng là nhân tố quyết định mọi thắng lợi của cách mạng Việt Nam [The sound and innovative leadership by the Party is the determinant of all victories of the Vietnamese Revolution]" Công an nhân dân [People's Police Newspaper] (29 January 20I 5), online: Công an nhân dân <http://cand.com.vn/thoi-su/ Cao-Su-lanh-dao-dung-dan-sang-tao-cua-dang-la-nhan-to-quyet-dinh-moi-thang-loi-cua-Cach-mang-Viet-Nam339942/>.

43. Nguyễn Phú Trọng made these comments in a televised speech at a meeting with officials of Vĩnh Phúc province on 25 February 2013. 
party-state did accommodate some of the demands of these societal groups. Towards the end of the public consultation period, the Constitution Amending Committee urged all state institutions at the central and local levels to extend the date until the end of September 20I3. The Constitution Amending Committee also designated more options for important articles in later versions of the draft constitutional amendments to be subject to discussion. In the end, there were some alterations to Article 4 with regard to the relationship between the party and the people, the accountability of the party to the people for its decision-making, and the legal framework governing party members.

More significantly, despite an assertion of the unified nature of state power, the 20I3 Constitution formally recognized several key elements for the first time, such as division, coordination, and checks between legislative, executive, and judiciary powers, which belong clearly to the National Assembly, the government, and the courts. In fact, such syncretism is generating substantive conditions for the separation of powers. These culminated in Article 2 of the 2013 Constitution, which reads:

I. The Socialist Republic of Vietnam is a socialist law-based state of the People, by the People and for the People.

2. The People are the masters of the Socialist Republic of Vietnam; all state powers belong to the People whose foundation is the alliance between the working class, the peasantry and the intelligentsia.

3. The State powers are unified and delegated to state bodies, which shall coordinate with and control one another in the exercise of the legislative, executive, and judiciary powers.

If we juxtapose Article 2 alongside Article 4, a plain reading of the provisions suggests that the Party exercises ultimate and effective control over the legislative, executive, and judiciary powers. What is uncertain, however, is the extent to which the Party remains enmeshed in the actual day-to-day operations of these state institutions and allows them a degree of autonomy to coordinate with and control each other. The Party's statutes and resolutions place strong emphasis on the strategic role of the Party in leadership. However, in practice, the actual leadership of the Party has been more skewed towards micro-management by providing specific instructions and directives on the actual operations of state institutions. The enduring strength and influence of the Party rests in the capacity of the CPV to spell out the strategic role of the party vis-a-vis its leadership over state institutions. In order to move forward, this is the key question that any institutional reform in Vietnam needs to provide a comprehensive and coherent answer to. If this question remains unaddressed, the party-state will only continue to provide less effective solutions to current governance problems, particularly those relating to a number of important issues such as the freedom of association, the right to access information, state secrets, and the state budget.

The constitutional norm concerning the CPV in Article 4 of the Constitution has direct implications for the exercise of the freedom of association, which is provided in Article 25 of the Constitution. First, it triggers debates about the legal right to form independent political parties. Taking a unitarist approach, the party theorists pointed out that there is no basis for people to form any independent political party. Professor 
Vũ Minh Giang from the CPV Central Theoretical Council reiterated that the existing legal framework does not allow the establishment of any new political party and any such political project would be impossible. ${ }^{44}$ Previously the mouthpiece of the Vietnamese People's Army, Professor Nguyễn Thanh Tú virtually reinforced this position by claiming that "no other political force but the Party can gather enough ability to lead the country now or in the future". ${ }^{45}$ They effectively affirmed the longstanding position of the CPV leadership on denying political pluralism. Human Rights Watch also recognized that the right to form independent political parties is prohibited in Vietnam, and in this respect, it has criticized Vietnam for failing to provide for a fundamental right of the people to freedom of association as stated in Article 25 of the International Covenant on Civil and Political Rights (ICCPR). ${ }^{4}$ However, some lawyers have seriously questioned the argument about the lack of legal basis for forming new political parties. Lawyer Nguyễn Lệnh argued that even though the legal framework for the exercise of freedom of association is restrictive, it in no way prohibits the inception of a new political party. He pointed out that since the 1992 Constitution, the country's constitution no longer defines the CPV as the only force leading the state and society, and it has, in fact, legally opened up a new window for establishing a new political party other than the CPV. ${ }^{47}$

In another strong defence of the view that there is sufficient legal basis for forming a new political party in Vietnam, lawyer Trần Vũ Hải drew on the Constitution, the I957 Law on the Right to Form Associations, ${ }^{48}$ Decree $45 / 2010 / N D-C P,{ }^{49}$ the 2005 Civil Code, and other laws to demonstrate that a legal right to form a new political party exists. ${ }^{\circ}$ Based on an analysis of these legal documents, he concluded that a political party (or a political organization) is a special legal entity formed at the initiative of organizations and individuals through an incorporation of articles (charter or statute). This does not require recognition or approval from the state, as long as the political organization does not have a purpose of overthrowing the current regime. ${ }^{5 \mathrm{I}}$ This legal framework indeed extends to the formation of political-social organisations like the Vietnam General Confederation of Labour (VGCL), the Women's Association, the Farmers' Association, Vietnam Veterans' Association, the Ho Chi Minh Communist Youth Union, and the Vietnam Fatherland Front, which is a political

44. VŨ Minh Giang, "Căn cứ đâu để lập chính đảng mới? [What are the grounds for establishing a new political party?]” BBC Vietnamese (I7 August 20I3), online: BBC Vietnamese <http://www.bbc.com/ vietnamese/multimedia/20I3/08/I308I7_vuminhgiang_on_new_party.shtml>.

45. Hoang, supra note 32.

46. ONA, supra note $3 \mathrm{I}$.

47. NGUYẼ̃̂N Lệnh, "Đã có đủ căn cứ pháp lý để thành lập một đảng khác ngoài Đảng Cộng sản Việt Nam [There are sufficient legal grounds for establishing a new political party other than the Communist Party of Vietnam]" (30 August 2013), online: Ngoclinvugia's Blog <https://ngoclinhvugia.wordpress.com/ 2013/08/30/da-co-du-can-cu-phap-ly-de-thanh-lap-mot-dang-khac-ngoai-dang-csvn-ls-nguyen-lenh/> .

48. I957 Law on the Right to Form Associations (promulgated 20 May 1957).

49. Decree 45/20Io/ND-CP on the Organization, Operation, and Management of Associations (adopted 2I April 20IO).

50. TrẦn Vũ Hải, "Request to the National Assembly Standing Committee to comment on the issue of forming and participating in another political party other than the Communist Party" Boxitun (23 August 20I3), online: Boxitvn <http://boxitvn.blogspot.com/2013/o8/ls-tran-vu-hai-gui-uy-ban-thuong-vu.html>.

5I. Ibid. 
alliance as defined in Article 9 of the Constitution. These organizations were formed without the approval of the state and their statutes (or revised statutes) do not require recognition or approval from the state. The existence of the right to form a new political party in legal terms is actually in line with Vietnam's commitment under international human rights law on the freedom of association. The UN Human Rights Committee provides an authoritative interpretation of the ICCPR that "the right to freedom of association, including the right to form and join organizations concerned with political and public affairs, is an essential adjunct to the rights protected by Article 25 ".52 Therefore, there is sufficient legal basis for exercising the right to form independent political parties. The competent authorities of the state (the Standing Committee of the NA) and the party leaders, however, have remained silent on this question.

Another implication of Article 4 is that it has led to regulatory authorities excluding political and socio-political organizations from the sphere of regulation. The 1957 Law on the Right to Form Associations, Decree 88/2003/ND-CP, ${ }^{53}$ Decree 45/2010/NDCP or the various drafts of the Law on Associations explicitly exclude the political and socio-political organizations from their scope of regulation. In Vietnam's legal terms, the definition of associations does not apply to the organizations concerned with political affairs. An association must have its statute recognized and approved by competent state authorities to become a legal entity.

The constitutional norm on the party also bears a number of consequences on many other issues, for example, the right to access information, state secrets, and the state budget. On these matters, the existing legal framework refrains from setting limits on the discretionary power of the party while imposing sanctions on the infringement of the party's interests. In the many drafts of the Law on Access to Information, ${ }^{54}$ all state agencies, including the NA, the State President, the Government, Ministries, the SPC, and the SPP are obligated to provide information at the request of citizens. However, party organizations are not obliged to do so. Indeed, party organizations are not included or mentioned at all in the draft Law on Access to Information. Meanwhile, a number of party documents are classified as top secret in the law on state secrets. The party budget comes mainly from the state budget, but the former remains a secret and it has never been openly discussed at the National Assembly, which is the highest representative body of the people. An exceptional case was the unusual disclosure of the estimated budget of the CPV Central Office for 2014 in the total estimated budget for ministries and central agencies for 2014 attached to Decision $3016 / Q D-B T C$ dated the $12^{\text {th }}$ of April 2013 issued by Finance Minister. Accordingly, the CPV Central Office had an estimate of US\$98.6 million budget for the year 20I $4 .{ }^{55}$ The current legal and constitutional framework is designed in such a way that the Party cannot be held truly

52. UN Human Rights Committee, General Comment No 25 on the right to participate in public affairs, voting rights and the right of equal access to public service (Art 25), (Fifty-seventh session, I996), UN Doc $\mathrm{CCPR} / \mathrm{C} / 2$ I/Rev I/Add 7 (1996), para 27.

53. Decree 88/2003/ND-CP dated 30/7/2003 issued by the Government on the Organization, Operation and Management of Associations (promulgated 30 July 2003).

54. Law on Access to Information (promulgated 6 April 20I6, effective I July 20I 8).

55. Out of the 2014 total estimated budget of US\$4 8 billion, the estimated expenditure of the CPV Central Office alone accounted for more than 2 percent. 
accountable for any decisions it makes pertaining the state budget or its handing over of information to the public. Therefore, the specific role the CPV and its accountability has increasingly become "an elephant in the room" in various debates about legal norms. Even a law on the CPV, if enacted, can only be a starting point for further discussion on its clearer role and mandate on many important questions of governance.

\section{CONCLUSION}

The basic norm of a permanent, single-party leadership has been instituted in the Constitution of the Socialist Republic of Vietnam (SRV Constitution) since I980, forming the over-arching foundation - whether explicit or otherwise - for current constitutional and legal norms. The continued practice of state institutions in ensuring the consistency of the constitution and the legal system along this paramount principle has enabled it to become the most influential regulative and constitutive norm dominating any process of constitution-making and law-making. However, slavish adherence to this basic norm by state institutions and officials has reduced the Party's role from providing strategic leadership to being a mere managerial authority. This, in turn, makes it increasingly difficult for the Party to effectively handle broad governance problems. The frequent amendments of the SRV Constitution over the past few decades partly reflected the challenges that the Party is dealing with in matters of governance.

The most recent process of amending the constitution between $20 \mathrm{II}$ and $20 \mathrm{I} 3$ raised unprecedented contestations and challenges on the rational and constitutional grounds for the basic norm of permanent single-party leadership. As the discourse about party leadership supremacy illustrates, this grundnorm was seen either as a problem or as a solution to governance issues, or both. What makes the recent constitutional amendment process a major milestone is that the discursive power in these contestations has shaken the rationality-based legitimacy of this basic norm to its root. It raised many valid questions about a law on the party to put legal constraints on the party's power and to clarify the party's strategic leadership role, the right to form independent political organizations, and various issues related to the existing legal framework on the state institutions and citizens' rights and obligations. The constitutional norm of party leadership has created dilemmas in various laws that have been made or are in the making. Whether this grundnorm can retain its purchase will depend, to a large extent, on how successfully the Vietnamese party-state addresses the increasing tension between this norm and other norms, both constitutional and legal. 